\title{
The End of Panopticon/panopticism in William Gibson's Mona Lisa Overdrive : A Baudrillardian Reading
}

\author{
Hanieh Zaltash (Corresponding Author) \\ Islamic Azad University, Central Tehran Branch, Iran \\ E-mail: hnh_zaltash@yahoo.com \\ Farid Parvaneh \\ Department of English Language and Literature, Islamic Azad University, Qom Branch, Iran \\ E-mail: faridparvaneh@gmail.com
}

Received: 24-05-2014

Accepted: 04-07-2014

Published: 01-11-2014

doi:10.7575/aiac.ijalel.v.3n.6p.85

URL: http://dx.doi.org/10.7575/aiac.ijalel.v.3n.6p.85

\begin{abstract}
This paper seeks to examine William Gibson's Mona Lisa Overdrive as a cyberpunk novel in the light of Baudrillard's theory of "Simulation". Jean Baudrillard believes that reality is replaced by "hyperreality" and human beings live in a total "simulation" in which everything, such as power might be simulated. Thus, according to Baudrillard, power exists just as "the simulation of power" which is the result of "the circularization of power" between the dominator and the dominated. Baudrillard delineates "the circularization of power" through criticizing Michel Foucault's theories regarding power and panopticon, and introduces "the end of panopticon" which is centered upon the reversibility of the positions of the observer and the observed. In a meticulous analysis of TV performance of the Loud family in 1971, Baudrillard claims that the panoptic system is ended through playing on the opposition of seeing and being seen. The findings suggest that Mona Lisa Overdrive depicts "the end of panopticon," in a sense that Angie Mitchell in this novel can be considered as a counterpart for Baudrillard's instance of the Loud family. Indeed, this study attempts to elucidate "the end of panopticon" in Mona Lisa Overdrive (1988) through scrutinizing Angie Mitchell's way of living.
\end{abstract}

Keywords: Hyperreality, Simulation, Simulation of power, Panopticon, Foucault, The end of Panopticon, Mona Lisa Overdrive, William Gibson, Jean Baudrillard

\section{Introduction}

Mona Lisa Overdrive by William Gibson is one of the best examples of cyberpunk novel. The novel appears third in the Sprawl Trilogy after Neuromancer and Count Zero. The events of the novel take place eight years after the eight years in Count Zero and fifteen years in Neuromancer. The novel centers around life of characters with different identities in the form of simstim career and life on the chip. The genre of science fiction might fall into the category of "Simulation" and "Hyperreality" in Jean Baudrillard's theory. Gibson represents two types of 'the hallucinatory signs of power'; the Artificial Intelligences (AIs) and the voodoo gods, in order to highlight 'simulation of power' in his novels. By portraying the ambiguous entities of the AIs and the voodoo gods, Gibson intends to indicate that they do not have real power although they seem to be at the head of power structures and everything is under their control in the novels.

\section{Theoretical Framework}

"Simulation" and "hyperreality" in Baudrillard's writings can be considered as the key concepts to understand his theories. In his Simulacra and Simulation, Baudrillard states that "simulation" is "the generation by models of a real without origin or reality: a hypereal" (1). This statement delineates the both concepts; "simulation" and "hyperreality," simultaneously. Since "simulation is not an imitation, but a replacement" (Hegarty 50), Baudrillard expresses that reality is replaced by hyperreality. Therefore, human beings live in "a total simulation" (Hegarty 9) in which, according to Baudrillard, everythimg might be simulated, such as power. Baudrillard believes that "power no longer succeeds in producing the real, in reproducing itself as real, or in opening new spaces to the reality principles, and it falls into the hyperreal and vanishes: this is the end of power" (Forget Foucault 45). According to him, this is what Foucault cannot see; the death of the real power. He does not even refer to 'the simulation of power' (Baudrillard, Forget Foucault 50). Baudrillard elucidates that "power is in essence no longer present except to conceal that there is no more power, a simulation that can last indefinitely" (Simulacra and Simulation 17). So the absence of the real power results in "the simulation of power." Furthermore, Baudrillard expresses that "power is something that exchanged . . . . power is executed according to the reversible cycle of seduction," so "power seduces by that reversibility which haunts it" (Forget Foucault 52-53). Therefore, one can attribute 'the circularization of power' to this cycle of seduction. This idea becomes more conspicuous by expanding on 'the circularization of power' through Baudrillard's words:

There is no instance of power, no instance of transmission - Power is something that circulates and whose source can no longer be located, a cycle in which the positions of the dominator and the dominated are 
exchanged in an endless reversion that is also the end of power in its classical definition. The circularization of power ... puts an end to any localization of instances and poles. (Simulacra and Simulation 27)

Indeed, the circularity of the poles is the main reason for 'the circularization of power' between the dominator and the dominated. In other respect, 'the circularization of power' refers to the absence of the real power, in a sense that if power becomes reversible, it no longer exists except as 'the simulation of power' (Baudrillard, Forget Foucault 51-53). Therefore, the reversibility of the positions divulges 'the simulation of power.

'The circularization of power' can be more comprehensible by delineating Baudrillard's theories regarding "the end of panopticon." Seemingly, he presents this concept to challenge Foucault's notion of "panopticon" the architectural figure which was presented by J. Bentham in 1843. It was a special kind of prison which consisted of an annular building at the periphery and a tower at the center in which there is a supervisor who observes the prisoners who are in the cells of the annular building. Each cell has two windows; one is on the inside through which the supervisor/guardian can observe the prisoners and the other is on the outside through which the light crosses the cell from one end to the other. In contrast to the light of the cells, the tower is in total darkness, so the guardian can observe the prisoners without letting them see him. They cannot even understand when they are being observed. The design is emphasized by Foucault as a means which provides the authorities with power to control the individuals by observing them. He states that the panoptic system is a system in which the one "should be constantly observed" by an observer, and also the observed "knows himself to be observed" although he does not know when he is being observed (Foucault 200-201). While Foucault presents the panoptic system as a system which provides the observer with constant surveillance and control over the observed, Baudrillard challenges it by referring to the instability of the positions of the observer and the observed. He believes that in the new era, the positions of the dominator/observer and the dominated/observed are no longer distinguishable, and this is 'the end of the panopticon.' Baudrillard supports his ideas with having recourse to the example of TV performance of the Loud family in 1971. The process of filming the Loud family was done without a script or a screenplay. Moreover, there was an illusion that the family members were living as if the cameras were not there. According to Baudrillard, this is "an absurd, paradoxical formula - neither true nor false: Utopian," and this paradox fascinates everyone, or rather everyone is fascinated by the pleasure of "the microscopic simulation" that leads the real to pass into "the hyperreal.' This is what Baudrillard means by "the aesthetics of hyperreal" which fascinates everyone. On the other hand, the status of the family; "a typical ideal American family, California home, three garages, five children, assured social and professional status, decorative housewife, upper-middle-class standing," makes them hyperreal and leads to their death. Indeed, they might have been chosen in order to be glorified and died beneath the flames of the medium, or the camera lens which manipulate the truth, so the truth is no longer "the truth of the panoptic system, and of the gaze." Moreover, the truth is manipulated by "playing on the opposition of seeing and being seen." Regarding this very example, Baudrillard states that "you no longer watch TV, it is TV that watches you (live) ... a switch from a panoptic mechanism of surveillance . . . to a system of deterrence, in which the distinction between the passive and the active is abolished," so "it becomes impossible to locate one instance ... of power . . because you are always already on the other side" (Simulacra and Simulation 18-20); therefore, this is "the end of the panoptic system." According to Baudrillard, the best way to reveal the end of the panoptic system is demonstrating the reversibility of the positions of the observer and the observed. Therefore, this study scrutinizes William Gibson's Mona Lisa Overdrive (1988) in order to portray the end of panoptic system in this novel.

\section{Mona Lisa Overdrive in the Light of Baudrillard}

Mona Lisa Overdrive (1988) the last novel of Gibson Sprawl Trilogy represents a new system in which "panopticism" is ended. Although Gibson challenges the panoptic system through portraying the characters' struggle to escape panoptic system and the circularity of the positions of the observer and the observed in his previous novels, Neuromancer (1984) and Count Zero (1986), the end of panopticism reaches its pinnacle in Mona Lisa Overdrive (1988). This very novel is divided into four stories which are interwoven. One of the stories is focused on Angie Mitchell who has been introduced in the previous novel, Count Zero (1986), as a character that has a biochip in her head. The biochip has been put in her head by her father in order to enable her to access cyberspace directly. In the beginning of Mona Lisa Overdrive (1988), Gibson clarifies that Angie had passed the detoxification process and now is under Hilton Swift's observation. Indeed, from the beginning of the novel, Angie's status is highlighted in the system of observation. Thus, the end of panoptic system in Mona Lisa Overdrive (1988) pivots on Angie Mitchell. It is very likely that Gibson's portrait of 'the end of the panoptic system' draws an analogy between Angie Mitchell in Mona Lisa Overdrive (1988) and Baudrillard's example of the Loud family. Just as Baudrillard introduces his theories regarding 'the end of the Panopticon' by referring to the process of filming the Loud family as an instance, so Gibson demonstrates 'the end of the panoptic system' by describing Angie Mitchell's residence in which there are cameras for filming Angie's life:

The house crouched ... and her walks along the beach ... She was accompanied, on these walks, by an armed remote, a tiny Dornier helicopter that rose from its unseen rooftop nest when she stepped down from the deck. It could hover almost silently, and was programmed to avoid her line of sight. There was something wistful about the way it followed her, as though it were an expensive but unappreciated Christmas gift.

She knew that Hilton Swift was watching through the Dornier's cameras. Little that occurred in the beach house escaped Sense/Net. ... (Mona Lisa Overdrive 16) 
These lines refer to the beginning of a new system in which the panoptic system is ended. It seems that there are some similarities between the Louds and Angie; the first one, as mentioned above, is the process of the uninterrupted shooting which is described by Gibson's emphasis on the presence of the cameras in Angie's residence. The cameras are equipped with the facility for following Angie even if she is outside:

She hurried out of the house, down the stairs, ignoring the hum of toy Dornier's prop as it lifted off behind her like a patient dragonfly.

And Angie fell to her knees in the sand, the sound of the surf crashing around her, dazzled by the sun. The Dornier was hovering nervously in front of her, two meters away. . . . The remote's cluster of cameras whirred and rotated....

The Dornier darted forward, then back. (Mona Lisa Overdrive 18, 20)

So the cameras are following her and shooting every minute of her life. The second one is the illusion of filming as if no one is there, or rather the illusion of living as if no one is there:

'Thank you, Hilton, but. . . . I don't want anybody. ...'

'There's no one at the house, Angie.'

'Good. That's what I want, Hilton. No one at the house. The house, empty.'

$\ldots$

'I need a week,' she said. 'One week. Seven days. Alone.' (Gibson, Mona Lisa Overdrive 17-18)

In spite of the presence of the cameras at Angie's house, Hilton Swift keeps insisting that there is no one there. This is what Baudrillard calls "an absurd, paradoxical formula - neither true nor false: Utopian," and this paradox fascinates everyone because "there one sees what the real never was," in other words, the pleasure is "in the microscopic simulation that allows the real to pass in to the hypereal" (Simulacra and Simulation 18-19). Regarding this very idea, Hilton's statement; "No one at the house. The house empty," can be a misleading statement because it is neither true nor false, or rather it is an absurd, paradoxical formula which fascinates everyone. So the third one is the pleasure of seeing the hyperreal which is represented in Mona Lisa overdrive (1988) through one of the main characters, Mona Lisa who is a fan of Angie Mitchel:

'You like stims, Mona?' Prior asked, still smiling.

'Sure,' she said, 'who doesn't?'

'Have a favorite, Mona, a favorite star?'

'Angie,' she said, vaguely irritated. 'Who else?'

'Look,' he said, 'your favorite.' He was standing besides the bed's upholster headboard. There was a stim unit there, built in, and a little shelf with a set of trodes in a plastic wrapper and about five cassettes. 'All of Angie's new stims.' (Gibson 63, 64)

Indeed, everyone is fascinated by the pleasure of "the microscopic simulation" that leads the real to pass into "the hyperreal' as Mona and the other ones who are interested in Angie's life follow her life through jacking in her stims or through watching her on the screens which are in the public places:

There was a vid behind the bar, up over the bottles, and then she saw Angie there, looking square into the camera and saying something, but they had the sound down too low to hear over the crowd. Then there was a shot from up in the air, looking down on a row of houses that sat right at the edge of a beach, and then Angie was back, laughing and shaking her hair and giving the camera that half-sad grin.

'Hey,' she said to the bartender, 'there's Angie.'

'Who?'

'Angie,' Mona said, pointing up at the screen. (Gibson, Mona Lisa Overdrive 84)

\section{Conclusion}

The novel seems to be reflecting what Baudrillard means by "the aesthetics of hyperreal", which fascinates everyone. It can also be regarded that Angie is already hyperreal by her post-humanistic existence. There is a biochip in her head which enables her to access cyberspace directly. Indeed, her father has sacrificed her through making her hyperreal. Moreover, Gibson foreshadows Angie's sacrificial status in the third chapter of the novel. In this chapter, Gibson states that Angie finds out that her life has been sacrificed by his father; "Her father was dead . . and the record he'd kept of his life had told her little enough . . . that his reward had been knowledge, and that she had been his sacrificed" (Mona Lisa Overdrive 18). It seems that Angie's status is close to the Loud family's in regard to be chosen, glorified, and died beneath the flames of the medium. So the last similarity is the sacrificial process which leads to death. Baudrillard believes that at this point truth, which is no longer the truth of the panoptic system or of the gaze, is manipulated through the camera lens which pierces lived reality and puts it to death (Simulacra and Simulation 19). In other words, 
the camera lens penetrates the real, makes it hyperreal, and violates the panoptic system, so this is 'the end of the panoptic system.' It is very likely that Gibson portrays the sacrificial process by Angie's presence in the novel. She is an ideal heroine of the post-humanistic way of life, she is chosen to be glorified and died. Indeed, Gibson completes the sacrificial process by representing Angie's death at the end of the novel. This is how the panoptic system is ended in the last novel of Gibson's Trilogy by playing on the opposition of seeing and being seen. Therefore, there is no longer any distinction between two poles; the observer and the observed, which results in entering into 'simulation,' or rather 'simulation of power.'

\section{References}

Baudrillard, J. (2007). Forget Foucault. Trans. Los Angeles: Semiotext (e).

---. (1994). Simulacra and simulation. Trans. Sheila Faria Glaser. Michigan: University of Michigan Press.

Blackford, R. (2004). Reading the Ruined Cities.Science Fiction Studies. 31:2. 264-270.

Cavallaro, D.(2000). Cyberpunk and Cyberculture: Science Fiction and the work of William Gibson. Athlone Press.

Foucault, M. (1977). Discipline and punish: The birth of the prison. Trans. Alan Sheridan. New York: Vintage,

Gibson, W. (1988). Mona Lisa Overdrive. N.p:N.p.

Hegarty, P. Jean Baudrillard: live theory. London and New York: Continuum.

Henthrone, T. (2011). William Gibson: a literary companion. Macfarland \& Company, Inc Publishers. 